\title{
EM TORNO DO CARNAVAL E DA CULTURA POPULAR
}

Maria Laura Viveiros de Castro Cavalcanti

Carnaval e cultura popular são noções imbricadas. Este artigo examina o lugar central ocupado pelo carnaval entendido como agregado ritual peculiar e como conceito que sintetiza os elementos essenciais da ideia de festa - nas formulações sobre a cultura popular propostas por dois livros clássicos: A Cultura Popular na Idade Média e no Renascimento, do crítico literário russo Mikhail Bakhtin (1987[1965]), e Cultura Popular na Idade Moderna, do historiador inglês Peter Burke (1989 [1978]. Nesse debate, examinam-se o legado do Romantismo na conceituação da cultura popular, a ideia do carnaval como abrigo da visão de mundo festiva e grotesca da cultura cômica medieval e questões relevantes para a compreensão dos processos culturais de modo geral, tais como as noções de grande e pequena tradição, de niveis de cultura, de heterogeneidade cultural, de mediação e interação sociocultural. [abstract on page 277]

CARNAVAL, CULTURA POPULAR, MIKHAIL BAKHTIN, PETER BURKE, ROMANTISMO, RISO GROTESCO. 
Ele brincou com os homens e com os deuses celestes de tal maneira que nem os homens, nem os deuses se ofenderam com isso (de Etienne Pasquier, citado por Bakhtin a propósito de Rabelais)

Carnaval e cultura popular são noções imbricadas. ${ }^{1}$ O lugar ocupado pelo carnaval na configuração da cultura popular e da própria ideia de cultura popular é tema mar-

1 Este artigo retoma o texto de trabalho inédito que, realizado em 1990, preparou a abordagem do carnaval desenvolvida em minha tese de doutoramento, defendida em 1993 e publicada no ano seguinte. Ver Cavalcanti, 2006. Ver também sobre o carnaval Cavalcanti, 1999.

20 livro, só publicado em 1965, foi originalmente uma tese, completada em 1940, embora só defendida em 1946. Bakhtin nasceu em 1895 e morreu em 1975. Ver a respeito de sua obra Todorov, Tzvetan, 1984. cante em dois livros que, tão logo publicados, se tornaram referências para os estudiosos do assunto: $A$ Cultura Popular na Idade Média e no Renascimento, do crítico literário russo Mikhail Bakhtin (1987[1965]), ${ }^{2}$ e Cultura Popular na Idade Moderna, do historiador inglês Peter Burke (1989 [1978]).

Pelo viés de seu interesse literário, ao indicar a interação entre os diferentes níveis de cultura de uma época em sua vigorosa interpretação da obra de François Rabelais, Bakhtin elaborou a dimensão civilizatória do carnaval e seu papel ativo na conformação da cultura pública e grotesca medieval. Interessado em examinar a conformação histórica da cultura popular, Peter Burke, por sua vez, enfocou a festa carnavalesca como um dos elementos-chave na constituição do repertório comum à cultura popular ocidental entre os séculos XVI e XVIII. Na argumentação de ambos, o carnaval ocupa lugar de destaque na discussão da natureza, da unidade e na própria ideia de cultura popular. Os dois livros sobre os quais nos debruçaremos fornecem, portanto, sugestões tanto para o entendimento amplo do carnaval como processo sociocultural como para a apreensão do horizonte de questões propostas pela noção de cultura popular.

Nesse debate, emergem questões conceituais instigantes para a compreensão dos processos culturais de modo geral. Pois, por si só, a ideia de cultura popular traz implícita a necessidade de qualificar formas distintas e simultâneas de cultura que convivem ao longo de uma época, no interior de uma sociedade ou dos mesmos grupos sociais. Não é sempre, afinal, como sabido, que acrescentamos à "cultura" o adjetivo "popular". Ao indicar algum tipo de particularidade, a noção de cultura popular clama pelo desenvolvimento de formas de conhecimento que deem conta de sistemas ou processos socioculturais amplos, pois ela demanda a percepção da heterogeneidade cultural inerente à constituição dos grupos humanos.

\section{A CULTURA POPULAR VISTA POR UM HISTORIADOR DA CULTURA}

Burke define-se como historiador da cultura bastante próximo da perspectiva antropológica. Cultura, ele afirma, é atribuição de sentido e, já na introdução, qualquer nuança reificadora que a adjetivação do termo "historiador" pelo termo "cultura" possa sugerir se desfaz: "os historiadores da cultura deveriam definir-se não em termos de uma 
área ou 'campo' particular como a arte, a literatura e música, mas sim de uma preocupação distintiva com valores e símbolos" (BURKE, 1989, p. 27). Na prática, contudo, apesar de a definição de cultura utilizada abarcar todo tipo de construções (de artefatos a formas de comportamentos), o livro, ressalta o autor, concentra-se numa série mais estreita de objetos e atividades (imagens, material impresso, habitações, conto, danças, representação teatral e participação em rituais), e empenha-se em situá-los em contexto amplo. Geograficamente, o universo de referência abarca o conjunto da Europa, da Noruega à Sicília, da Irlanda aos Urais. Temporalmente, abrange os séculos XVI, XVII, XVIII.

E o adjetivo "popular"? Como entendê-lo? No sentido mais óbvio, seguindo Gramsci, cultura popular seria a cultura não oficial, da não elite, das classes subalternas, dentre as quais, no início da Idade Moderna, destacavam-se os artesãos urbanos e os camponeses. A simplicidade da resposta seria, entretanto, enganosa e insatisfatória, e o livro trata, justamente, de qualificar o escopo, a complexidade e a particularidade da noção de cultura popular e de compreender a configuração histórica do processo de sua conformação. ${ }^{3}$ Trata-se de apreender também o caráter histórico da própria noção 3 Sobre a noção de cultura popular, vale a pena ler também DaMatta, 1994. de cultura popular no quadro dos valores e ideais do Romantismo, poderosa corrente de pensamento que se desenvolve na Europa na segunda metade do século XVIII.

\section{OS LIMITES E A HISTÓRIA DO CONCEITO DE CULTURA POPULAR}

Peter Burke assinala a coincidência histórica, em finais do século XVIII e começo do seguinte, entre o início do desaparecimento de uma "cultura popular tradicional", na qual participavam diferentes camadas sociais, e o surgimento do povo como tema de interesse intelectual específico. A organização, por Herder, entre 1760 e 1846, de inúmeras coletâneas sobre canções populares nacionais, o interesse pelo conto popular dos irmãos Grimm nas primeiras décadas do século XIX, a cunhagem do termo folclore, em 1846, por Williams John Thoms, para denominar um campo de estudos até então identificado como "antiguida4 Ver a esse respeito, $\mathrm{Ca}$ valcanti et alii, 1992. des populares ${ }^{4}$ indicariam claramente esse novo interesse.

Por trás dos termos, delineiam-se valores e visões de mundo das camadas eruditas que logo conformariam uma perspectiva ortodoxa do universo cultural popular. Em 1778 , em seu "Ensaio sobre a influência da poesia nos costumes dos povos nos tempos antigos e modernos" (1778), Herder compreendeu a poesia de outrora como parte integrante de um modo de vida particular. No mundo pós-renascentista, a eficácia moral da poesia estaria, no entanto, restrita à canção popular, que, acompanhada de música, circula oralmente, desempenhando funções práticas. O mundo do folclore e da cultura popular emerge como o abrigo nostálgico da totalidade integrada da vida com o mundo, rompida no mundo moderno; como o repositório do "espírito da nação". Nesse ímpeto intelectual, definem-se como temas de interesse intelectual toda a cultura tradicional, a religião e as festas populares. Herder, nos informa Burke, descreveu a festa de São João em Riga, 1760. Goethe, organizador de festas populares na corte de Weimar, tornou céle- 
bre, com sua descrição, o carnaval romano de 1788. Coubert inspirou-se em xilogravuras populares para compor suas pinturas (BURKE, 1989).

Nesse contexto intelectual, a concepção de povo foi construída em contraste, de um lado, com as camadas cultas da época e, de outro, com a plebe ou a ralé, fundamentando o valor positivo do elemento popular. $\mathrm{O}$ objeto privilegiado de estudos era o camponês, visto como o depositário da autêntica cultura do povo. Em especial, três características básicas qualificariam a visão romântica do popular (BURKE, 1989): o primitivismo, o comunalismo e o purismo. O primitivismo diz respeito à tentativa de localização da origem das expressões populares em um tempo primitivo indeterminado e abstrato: o antigo, o distante e o popular são equiparados. O comunalismo refere-se à ideia de que a poesia popular cresce e floresce espontaneamente, não existindo autor nem estilo individualizado. Na cultura popular, o papel da tradição e do passado da comunidade seria também maior do que o papel do indivíduo. ${ }^{5} \mathrm{~A}$ comunidade indiferenciada internamente é o indivíduo singular. O purismo fala das qualidades da produção popular como expressão dessa natureza simples e instintiva do povo.

Posteriormente (nem em Herder, nem nos Grimm, segundo Burke) essa descoberta se teria associado à ascensão do nacionalismo cultural e a uma série de

movimentos nativistas no sentido de tentativas organizadas de sociedades sob o domínio estrangeiro para revi-

5 Jakobson e Bogatyrev (1973 [1929]) trazem contribuição crucial para essa discussão ao enfocar a forma específica da criação artística no folclore.

6 Ver também, a esse respeito, Ortiz, 1985.

7 Para uma elaboração do tema da perda nos discursos sobre o patrimônio no Brasil, ver Gonçalves, 2002 e 2001.

80 mesmo tema integra o campo dos estudos de folclore no Brasil, onde o sentido de "urgência" foi fundamental nas iniciativas do Movimento Folclórico Brasileiro e, em especial, na constituição da Campanha de Defesa Brasileira do Folclore em 1949. Ver a respeito ViIhena, 1997 e Cavalcanti et allii, 1992. ver sua cultura tradicional (...). De maneira bastante irônica, a ideia de nação veio dos intelectuais e foi imposta ao 'povo' com quem eles queriam se identificar (BURKE, 1989, p. 40).

Em 1800, entretanto, como assinala o autor, a consciência de artesãos e camponeses era mais regional do que nacional.

O impulso filosófico e intelectual do Romantismo ocorreu ou originou-se, sobretudo, na periferia cultural da Europa. ${ }^{6}$ Essa "descoberta", entretanto, teria encontrado uma tradição mais antiga de interesse pelos usos e costumes, pela diversidade de crenças e práticas em diferentes partes do mundo, que remontava à Renascença e vinha tomando cunho mais sociológico no século XVIII (BURKE, 1989). Ela coincidiria, também, com a percepção do que se supunha ser um processo de desaparecimento do popular. O tema da degradação, da corrupção, do aniquilamento, por sinal eternamente retomado em nossa bibliografia brasileira sobre folclore e cultura popular, veio a compor assim o quadro de valores associados à cultura popular. ${ }^{7} \mathrm{~A}$ percepção de acelerado processo de transformação social em curso geraria nos intelectuais eruditos a consciência aguda da importância das tradições. ${ }^{8}$ 
Outro ponto fundamental no campo ideológico que se configura a partir da noção de cultura popular é a ideia de autenticidade, da existência de uma "tradição popular pura". A noção, como indica Burke, revela-se, entretanto, equivocada. Em primeiro lugar, há a dificuldade no uso das fontes que garantem o acesso aos fatos culturais populares. As coletâneas da época poderiam ser efetivamente consideradas fidedignas pelos critérios modernos? indaga-nos Peter Burke, citando o famoso caso de falsificação de Macpherson, suposto descobridor do homem celta, encarnado no bardo gaélico Ossian. Uma comissão da Sociedade das Terras Altas da Escócia, organizada no século XIX, teria chegado à conclusão de que alguns trechos da coleta de Macpherson seriam efetivamente tradicionais, mas, de modo algum, o conjunto. Macpherson havia completado lacunas, fornecido ligações e criara, portanto, algo novo. Entre a "falsificação" e a "edição" (como no caso dos Grimm), Burke acredita que a diferença seria antes de grau e não de natureza, pois qualquer acesso do historiador ao passado supõe a mediação das fontes documentais.

Essa compreensão fina da necessária mediação do documento no acesso ao "fato" é ponto de contato entre história e antropologia, ${ }^{9}$ e problematiza as possibilidades e os limites da compreensão da alteridade, esteja ela situada no tempo ou no espaço: "Estudar a história do comportamento dos iletrados é necessariamente enxergá-los com dois pares de olhos estranhos a ela: os nossos e os dos autores dos documentos que servem de mediação entre nós e as pessoas comuns que estamos tentando alcançar" (BURKE, 1989, p. 54).

Desse ponto de vista, uma "tradição popular pura" não só seria inatingível por uma condição de método, como, na ver-

9 Vale mencionar a elaboração dessa questão crucial - a presença da subjetividade do intérprete na construção de seus "dados" - pela antropologia contemporânea. Para uma discussão do tema na antropologia brasileira, ver DaMatta, 1978; Velho, 1978; e Cavalcanti, 2003. dade, ela inexiste. A noção de autenticidade originária supõe algum lugar da humanidade em que não haveria história ou processo em curso. Ora, não apenas os documentos, mas a própria realidade viva é sujeita a restaurações, ressignificações e reelaborações. É o caso notável das festas. O carnaval de Colônia, como exemplifica o autor, foi revivido em 1823, o de Nuremberg em 1843, o de Nice em meados do século XIX. Assim, "ler o texto de uma balada, de um conto popular ou até de uma melodia numa coletânea da época, é quase como olhar uma igreja gótica "restaurada" no mesmo período, a pessoa não sabe se está vendo o que existia originalmente, o que o restaurador achou que devia ter existido, ou o que ele achou que devia existir agora" (BURKE, 1989, p. 47).

Que momento, então, definiríamos como o instante zero do autêntico idêntico a si mesmo?

Outro problema da noção da autenticidade originária é a suposição da homogeneidade e uniformidade dos processos culturais. Ora, um dos pontos bastante enfatizados é justamente a grande variedade e diversidade internas à cultura popular tanto no ambiente rural quanto no urbano: "Não existia uma tradição popular imutável nos inícios 
da Europa Moderna, e talvez nunca tenha existido. Portanto, não há nenhuma boa razão para se excluir os moradores das cidades, ou seja, o respeitável artesão ou a 'turba' de Herder de um estudo sobre cultura popular" (BURKE, 1989, p. 49).

\section{OS NÍVEIS DE CULTURA E A GRANDE E A PEQUENA TRADIÇÃO}

O tema da heterogeneidade cultural sobrepõe-se, assim, à discussão do universo popular. A própria expressão cultura popular supõe, como vimos, a existência de diferenças culturais. No "modelo de duas camadas" a noção, contudo, é apenas contraposta a uma "cultura de elite" que sugere, enganosamente, homogeneidade interna a essas diferentes camadas sociais. Burke, no entanto, busca deslocar esse modelo de pensamento, pois: "A fronteira entre as várias culturas do povo e as culturas das elites (e estas eram tão variadas quanto aquelas) é vaga. Por essa razão, a atenção dos estudiosos deveria concentrar-se na interação e não na divisão entre elas" (BURKE, 1989, p. 21).

A inspiração para esse deslocamento do interesse na demarcação de fronteiras entre níveis de cultura diferenciados ao interior de uma sociedade ou de um sistema cultural para a interação entre eles é a obra de Mikhail Bakhtin. A visão de uma oposição simples entre duas camadas de cultura (a erudita versus a popular) desloca-se, então, em duas direções: rumo à afirmação da heterogeneidade interna e constitutiva da cultura (seja ela popular ou erudita) e rumo à investigação da interação entre os distintos níveis de cultura de uma época social, bem como de sua natureza complementar.

Nesse duplo deslocamento, o texto clássico do antropólogo Robert Redfield Peasant Society and Culture (1956) inspira a reflexão de Burke sobre a formação da cultura popular na Idade Moderna, pois, em sua proposta de uma antropologia das sociedades complexas, Redfield fez da comunicação entre tradições culturais diversas no interior dos grupos humanos e entre esses diferentes grupos um tema central.

10 Redfield ressalta a coincidência entre o momento em que o mundo se está tornando uma grande sociedade e a invenção do primitivo pelos antropólogos. Estes últimos são justamente instrumentos na formação desse novo mundo.

\section{A GRANDE E A PEQUENA TRADIÇÃO}

Em seu livro, Robert Redfield (1956) preocupou-se em adequar o quadro conceitual da antropologia à expansão de seu objeto - dos grupos primitivos entendidos como pequenas totalidades altamente integradas à incorporação de "tudo que é humano". ${ }^{10}$ Ora, as sociedades não primitivas estudadas pelos antropólogos estariam cheias de cidades e instituições nacionais, sendo a diversidade sua característica. As sociedades camponesas (aquelas em que o modo de vida se organiza através do cultivo da terra e seu controle associado à tradição e ao sentimento, e não ao lucro e aos negócios) conformariam justamente um desses novos objetos que então se abriam à investigação antropológica. Redfield as define como part-societies (sociedades parciais), no sentido de que, para compreendê-las, é preciso dar conta do "organismo" mais amplo em que elas se incluem. Ora, na part-society camponesa destacamse exatamente as relações de influência cultural entre o segmento camponês e a elite do sistema social mais amplo. A distinção entre a grande e a pequena tradição é formula- 
da nesse contexto. A grande tradição seria conscientemente cultivada, a pequena, entretanto, vista como algo natural: "Na civilização, há a grande tradição dos poucos grupos reflexivos e há a pequena tradição dos muitos grupos amplamente irreflexivos". Ora, observa Redfield, essas tradições são interdependentes: "Afetaram-se mutuamente desde há muito tempo e continuarão a fazê-lo (...). A pequena e a grande tradições podem ser pensadas como duas correntes de pensamento e ação distinguíveis e, ainda assim, fluindo entre si" e interferindo uma na outra de modo permanente ${ }^{11}$ (REDFIELD, 1956, p. 87).

Interessa, portanto, entender, sobretudo, como uma tradição se torna parte da outra e como se influenciam mutuamente. Redfield conclui:

Concebida desse modo, a civilização é um contexto de pensamento com suas expressões em ações e em símbolos. Ela é compósita no sentido em que é feita de partes ou níveis, cada parte ou nível mais presente em algumas das pessoas portadoras dessa civilização do que em outras (...) essas partes ou níveis são diferentes de culturas locais, são diferentes das subculturas que caracterizam os grupos ocupacionais encarregados de especialidades seculares. Elas são diferentes porque o aprendizado da grande tradição é uma consequência da pequena tradição. A grande e a pequena tradições são dimensões uma da outra; aqueles que sustentam os níveis inferiores e aqueles que apoiam os mais elevados reconhecem igualmente a mesma ordem de "grandeza" e de "pequenez"12 (REDFIELD, 1956, p. 87).

\section{A CULTURA "POPULAR" TRADICIONAL. INTERAÇÃO SOCIAL E BILINGUISMO CULTURAL}

A aplicação desse modelo de pensamento à situação histórica da Europa Moderna por Peter Burke resulta na percepção de estratificação social e cultural que opõe "uma minoria que sabia ler e escrever a uma maioria analfabeta"; da grande tradição como a "tradição clássica, tal como transmitida nas universidades (...) e, fora disso, a pequena tradição: as canções e contos populares, as devoções; as farsas e peças de mistério; os folhetos e livros de baladas e sobretudo as festas" (BURKE, 1989, p. 51). O autor ressalta, em especial, a interação entre as diferentes camadas de cultura ao chamar atenção para a participação fundamental das classes altas na cultura popular, especialmente marcante nas festas. Embora útil, essa ideia seria, no entanto,
11 Tradução livre da autora: "In civilization there is a great tradition of the reflective few, and there is a little tradition of the largely irreflective many". [Essas tradições são interdependentes]: "Have long affected each other and will continue to do so (...) Great and little tradition can be thought of as two currents of thought and action distinguishable, yet ever flowing into and out each other" (REDFIELD, 1956, p. 87). 12 Tradução livre da autora: Conceived as such, civilization is a context of thought with its expressions in actions and symbols. It is composed in the sense that it is made of parts or levels, each present in some of the people that carry on that civilization more than in others (...). Those parts or levels are different from local cultures, are different from subcultures that charactherize the occupational groups in charge of secular specialties. They are different because the learning of the great tradition is a consequence of the little tradition. Great and little tradition are dimensions of one another; those who sustain the inferior levels and those who support the more elevated ones recognize equally the same order of "highness" and "lowness" (p. 87). 
anacrônica, pois, a elite não "participava" da "cultura popular" porque "(...) não associava baladas, livros populares e festas à gente comum, precisamente porque também participava ela mesma, dessas formas de cultura" (idem). O termo participar, por sua vez, é impreciso. Participar de uma festa não é a mesma coisa que participar de um sistema de crenças. A leitura e a escuta de contos populares pela nobreza podia significar interesse semelhante ao de alguns intelectuais de hoje (segundo Burke quanto mais se avança no século XVIII, mais essa interpretação seria provável). Muitos nobres e clérigos não sabiam ler, e o estilo de vida de alguns deles, sobretudo nas áreas rurais, não era muito diferen-

13 Para o personagem do mediador, ver Michel Vovelle (1978). Para a discussão da mediação cultural no contexto das sociedades urbanas, ver VeIho, 1981 e no contexto urbano carnavalesco, ver Cavalcanti, 2006 e 1999. te daquele dos camponeses ao redor. Sua proximidade da grande tradição seria relativa. Esse seria o caso também das mulheres nobres, que devem ser vistas como

intermediárias entre o grupo a que pertenciam socialmente, a elite, e o grupo a que pertenciam culturalmente, a não elite (...) os nobres, eruditos, mantinham contato com a cultura popular através de suas mães, irmãs, esposas e fiIhas, e em muitos casos, teriam sido criados por amas camponesas que lhes cantavam baladas e contavam-Ihes estórias populares ${ }^{13}$ (BURKE, 1989, p. 54-55).

A elite, então, participava da pequena tradição, e seria culturalmente bilíngue, digamos, mas o povo comum não participava da grande tradição. Apesar da notável assimetria sociocultural, a noção de cultura popular - aqui equivalente à ideia da pequena tradição de Redfiled - não corresponde ao subalterno. Os limites de uma cultura ou de uma tradição cultural não acompanham as fronteiras de classe ou de grupos. A distinção entre os diferentes níveis de cultura repousariam, antes, nos mecanismos de transmissão formal, num caso, informal, no outro:

A grande tradição era transmitida formalmente nos liceus e nas universidades. Era uma tradição fechada, no sentido em que as pessoas que não frequentavam essas instituições, que não eram abertas a todos, estavam excluídas. Num sentido totalmente literal, elas não falavam aquela linguagem. A pequena tradição, por outro lado, era transmitida informalmente. Estava aberta a todos, como a igreja, a taverna, e a praça de mercado. (BURKE, 1989, p. 56).

De acordo com Peter Burke, a noção romântica de cultura popular configurou-se ao longo dos séculos XVII e XVIII, com as elites deixando de participar da pequena tradição, de conhecer e de vivenciar códigos culturais distintos. A "invenção" da cultura popular supõe, então, o afastamento por parte da elite da cultura popular tradicional e a construção de uma nova forma, mais intelectiva e de certo modo mais distanciada, de aproximação das formas culturais agora percebidas como pertencentes ao "povo". Burke demonstra, desse modo, como a noção romântica de cultura popular corresponde a uma redefinição profunda e histórica dos parâmetros de um sistema cultural. 


\section{UNIDADE E FORMAÇÃO DA CULTURA POPULAR. O DIÁLOGO ENTRE PETER BURKE E MIKHAIL BAKHTIN}

Resta assim abordar o problema da unidade da cultura popular. Embora as diferenças internas e as variações do popular sejam inúmeras, e esse seja um ponto importante na revisão da própria noção de cultura popular, haveria na conformação da cultura popular um repertório comum, um conjunto de elementos a partir dos quais se construíram suas muitas variações e os diferentes padrões locais (BURKE, 1989, p. 81-82). Poderíamos pensar que as diferenças existem no plano das formas e expressões culturais concretas, mas que num plano mais abstrato alguma particularidade as uniria em uma mesma qualidade ou natureza. Um primeiro elemento de unidade seria representado pelos agentes sociais portadores das expressões populares: artistas e artesãos (contadores de estórias, músicos, pregadores e curandeiros, artistas de entretenimentos, mascates, pintores, entalhadores, tecelãos) em interação com seu público citadino e rural. Um segundo elemento estaria configurado nos próprios objetos e expressões produzidos (as canções, os contos, as peças e estampas, os artefatos, entre outros). O caráter eminentemente oral dessa produção cultural garantiria, segundo Burke, certa unidade dos padrões. Um terceiro elemento, finalmente, se apresentaria como as festas e os rituais, que ocupam lugar central nas sociedades tradicionais. Ora, a festa por excelência como contexto para imagens e textos é o carnaval, visto como agrupamento especialmente importante de rituais populares, forte sobretudo na área mediterrânea (Itália, Espanha e França), razoavelmente forte na Europa Central e mais fraco no norte europeu (Grã-Bretanha e Escandinávia), embora, de uma forma ou de outra, sempre presente e atuante.

Burke elabora então, a partir de dados fragmentários, uma descrição de um carnaval típico. Nessa ocasião, as principais ruas e praças da cidade imaginada transformavam-se em palcos, e os cidadãos, em atores e espectadores de um teatro sem paredes. Acontecimentos mais ou menos estruturados ocorriam: comilanças, uso de máscaras, travestismo, batalhas de farinha, laranjas, pedras e ovos. Alguns eventos mais organizados comportavam maior distinção entre atores e espectadores, e eram muitas vezes organizados por clubes ou confrarias dirigidas por "reis" ou "aba-

des" do desgoverno, concentrando-se nos últimos dias e nas praças centrais. ${ }^{14}$ As apresentações combinavam desfiles de car-

14 Ver a respeito Sidro, ros alegóricos, competições ou corridas, encenação de alguma 1979. farsa. Temas como sexo, comida e violência seriam recorrentes. O carnaval, informa Peter Burke, era época de desordem institucionalizada, um conjunto de rituais de inversão. “Não admira que os contemporâneos o chamassem de época de 'loucura' em que reinava a folia" (BURKE, 1989, p. 215). A definição da cultura popular, tal como elaborada por Peter Burke, engloba assim também, de modo notável, a natureza pública e ritual da festa carnavalesca que traz em si algumas qualidades e características de natureza peculiar. O diálogo com as formulações de Mikhail Bakhtin (1987) tornam-se, então, centrais para o desenvolvimento da argumentação de Peter Burke. 


\section{O CARNAVAL COMO VISÃO DE MUNDO E CULTURA NÃO OFICIAL}

Mikhail Bakhtin formulou com brilho e vigor a questão da interação entre os níveis de cultura em sua análise da obra de François Rabelais. O reconhecimento da influência de Rabelais não só nos destinos da literatura e língua literária francesas, mas também da literatura mundial, é seu ponto de partida. A história literária, entretanto, o teria compreendido, quando o fez, apenas parcialmente, por ignorar sua qualidade fundamental: "a de estar ligado, mais profunda e estreitamente que os outros às fontes populares (...), essas fontes determinaram o conjunto de seu sistema de imagens, assim como sua concepção artística" (BAKHTIN, 1987, p. 2). Na visão desse autor, Rabelais seria um sofisticado mediador a transitar entre as tradições popular e culta. Bom conhecedor da linguagem da praça e do mercado, Rabelais era também um erudito, formado em teologia e medicina, conhecedor dos clássicos, informado das leis. O uso da cultura popular para a escrita literária de Rabelais era, portanto, deliberado.

Embora o interesse primordial de Bakhtin seja estético e vise à compreensão filosófica do realismo grotesco como visão de mundo plena e potente, a imagem da cultura popular da Idade Média e do Renascimento - contexto social e histórico da germinação desse estilo artístico - emerge do exame empreendido. Trata-se, antes de mais nada, de uma cultura cômica, caracteriza-se por uso peculiar do riso. Embora as manifestações dessa cultura sejam infinitamente variadas (festas públicas carnavalescas, ritos e cultos cômicos especiais, os bufões e tolos, gigantes, anões e monstros, palhaços de diversos estilos e categorias), o exame proposto por Bakhtin é teórico e almeja revelar a unidade da cultura cômica popular seu "sentido e natureza ideológica profunda, i. e. o seu valor como concepção de mundo e o seu valor estético" (BAKHTIN, 1987, p. 50). Em Rabelais, justamente, a unidade interna de todos os elementos heterogêneos que compunham a cultura popular medieval revela-se com excepcional clareza e pode ser sintetizada pela expressão "cultura carnavalesca".

Numa acepção ampla, a cultura carnavalesca vem designar "toda a vida rica e variada da festa popular no decurso dos séculos e durante a Renascença". Num sentido estrito, carnavalesco refere-se ao processo por meio do qual os caracteres específicos do popular abrigaram-se gradativamente no carnaval à medida que a maior parte das outras formas populares foi desaparecendo. O sistema de imagens carnavalescas teria, portanto, sobrevivido historicamente no carnaval. O carnaval dos séculos XVIII e XIX conservaria de forma empobrecida, porém, nítida os traços particulares da festa popular, seus elementos essenciais: "pode-se afirmar, sem risco de erro, que é o fragmento mais bem conservado desse mundo tão imenso quanto rico" (BAKHTIN, 1987, p. 189). Goethe, em sua descrição do carnaval romano de 1788 , teria captado e formulado as características básicas do carnaval.

Num primeiro nível, a unidade da cultura popular medieval pode ser localizada numa diferença de princípio em relação às cerimônias oficiais da Igreja e do Estado feudal: 
O princípio cômico que preside aos ritos do carnaval, liberta-os do misticismo, da piedade, e eles são além disso completamente desprovidos de caráter mágico ou encantatório (não pedem nem exigem nada) (...). Por seu caráter concreto e sensível e graças a um poderoso elemento de jogo, elas [as formas carnavalescas] estão mais relacionadas às formas artísticas e animadas por imagens, ou seja, às formas do espetáculo teatral (BAKHTIN, 1987, p. 6).

Seu núcleo, todavia, não poderia ser reduzido ao artístico: "Ele se situa nas fronteiras entre a arte e a vida. Na realidade, é a própria vida apresentada com os elementos característicos da representação" (idem, ibidem). A cultura carnavalesca constituía, ao lado do mundo oficial, uma espécie de segundo mundo ao qual os homens da Idade Média pertenciam em maior ou menor proporção. ${ }^{15} \mathrm{~A}$ cultura carnavalesca associa-se assim ao não oficial.

Num segundo nível, a unidade da cultura cômica popular baseia-se em uma teoria da festa. A festividade, forma primordial da civilização humana, é indestrutível: "Ela pode empobrecer-se, às vezes mesmo degenerar, mas não pode apagar-se completamente (...)" (BAKHTIN, 1987, p. 240). Ela tem, na visão de Bakhtin, conteúdo essencial, sua sanção emana de "fins supe-
15 Bakhtin era, a sua própria maneira, um materialista histórico e associou esse caráter não oficial do riso carnavalesco ao surgimento da sociedade de classes e do Estado. Nas etapas primitivas do desenvolvimento humano, o cômico e o sério seriam igualmente oficiais. Com o surgimento das classes e do Estado, o sentido das formas cômicas se teria modificado: "elas complicamse e aprofundam-se para transformarem-se, finalmente nas formas fundamentais de expressão da sensação popular do mundo e da cultura popular" (BAKHTIN, 1987, p. 5). riores", do "mundo dos ideais": “(...) está isenta de todo sentido utilitário (é um repouso, uma trégua, etc.). É a festa que, libertando os homens de todo utilitarismo, de toda finalidade prática, fornece o meio de entrar temporariamente no universo utópico" (BAKHTIN, 1987, p. 240-241). Com sua sabedoria licenciosa, a festa confere direito à tolice. A festa oficial está do lado da ordem. O carnaval, do lado da utopia, é o reino da universalidade, da liberdade, da igualdade e da abundância: "a consciência da alegre relatividade das verdades e autoridades no poder" (idem, ibidem). É o mundo ao revés, a lógica do avesso que, ao negar, renova e ressuscita. O carnavalesco é um estado peculiar do mundo: "seu renascimento e renovação dos quais participa cada indivíduo". O denominador comum de todas as características carnavalescas que compreendem as diferentes festas populares reside na natureza peculiar de seu elo com o tempo: o "tempo que brinca e ri", que efetua o destronamento do antigo e o coroamento do novo. Nesse ideal de renovação localiza-se o caráter universal do carnaval, a essência do carnavalesco.

Num terceiro nível, esse estado peculiar do mundo se expressa de modo coletivo e concreto no realismo grotesco, forma estética e filosófica definida por três princípios. ${ }^{16} \mathrm{O}$ primeiro é a afirmação da vida material e corporal. O corpo do realismo grotesco tem caráter cósmico e universal, não coincide com seus limites individuais, é apreendido de forma utópica e festiva:
16 O termo grotesco surgiu, segundo Bakhtin, em finais do século $X V$, quando escavações feitas em Roma, nos subterrâneos das termas de Tito, revelaram um tipo de pin- 
tura ornamental até então desconhecido (grottesca, derivada de grotta, gruta). Decorações semeIhantes foram encontradas em outros lugares da Itália. Nelas não se distinguiam fronteiras claras entre os reinos vegetais, animais e humano. As formas transformavamse em outras, e eram essencialmente inacabadas. Concebidas como alegre liberdade e ousadia, essas decorações seriam fragmentos de um imenso universo que teria existido segundo o autor em todas as etapas da Antiguidade e que continuou existindo na ldade Média e no Renascimento (BAKHTIN, 1987). "como tal opõe-se a toda separação das raízes materiais e corporais do mundo, a todo isolamento e confinamento em si mesmo, a todo caráter ideal abstrato, a toda pretensão de significação destacada e independente da terra e do corpo" (BAKHTIN, 1987, p. 17).

O segundo princípio é o do rebaixamento, qualidade essencial, que o distingue das formas mais "nobres" da literatura. Consiste na transferência de tudo o que é elevado para o baixo topográfico, a terra, o corpo; essa degradação tem sentido simbólico profundo. Na sua base está a concepção de um universo descentralizado, no qual todos os lugares têm igual valor, a destruição da hierarquia confere o direito de transferir para debaixo da terra, por exemplo, o centro relativo do céu. A imagem do inferno, negando a horizontalidade do tempo histórico, condensaria para Bakhtin as características essenciais da oficialidade medieval, ao depreciar a terra e afastar-se dela. O inferno carnavalesco, entretanto, a sanciona; a terra é, ao mesmo tempo, túmulo e ventre, princípio de absorção e renascimento e renovação. 0 mesmo vale para o baixo corporal, os órgãos genitais.

A terceira qualidade é a ambivalência. As formas do realismo grotesco abrigam os dois polos de uma metamorfose; o antigo e o novo, o que morre e o que nasce. O corpo e o mundo

são apreendidos como essencialmente inacabados. Daí a ênfase nas excrescências e nos orifícios corporais: "nos lugares onde se ultrapassam, atravessam os seus próprios limites (...) que põem em campo um outro corpo: o ventre, o falo" (BAKHTIN, 1987, p. 277). Os corpos são corpos que copulam, devoram, fazem necessidades. A lógica artística da imagem grotesca "ignora a superfície do corpo e ocupa-se apenas das saídas, excrescências, rebentos, orifícios, i.e. unicamente daquilo que faz atravessar os limites desse corpo e conduz ao seu fundo" (BAKHTIN, 1987, p. 272). O despedaçamento do corpo, as tripas, as destruições e destronamentos, a flagelação, as batalhas, as grosserias e injúrias são todas "imagens concentradas sobre a unidade contraditória do mundo que agoniza e renasce" (BAKHTIN, 1987, p. 189). Essas imagens pertencem a um mundo bicorporal, em que nada é perfeito nem completo, a um mundo antioficial em perpétuo estado de inacabamento.

\section{O REALISMO GROTESCO COMO SISTEMA DE IMAGENS}

O sistema de imagens do realismo grotesco abriga o cerne da própria ideia de cultura carnavalesca e a unidade conceitual da cultura cômica popular na Idade Média. Compreender Rabelais em seus próprios termos é compreender o sentido utópico do realismo grotesco, e a história literária nem sempre o fez.

Na visão de Bakhtin, o século XVI representa o ponto máximo da "história do riso", a obra de Rabelais expressa esse apogeu, a fecundação da grande literatura da épo- 
ca pela cultura cômica popular. O riso, entretanto, iria gradualmente perder o elo essencial com a concepção de mundo, e a tradição viva do riso da festa popular começaria a desaparecer. ${ }^{17}$ O século XVII, com o racionalismo de Descartes e a estética do classicismo, marca o início desse processo. A literatura não está mais submetida à influência direta da cultura festiva popular.
17 Burke refere-se aparentemente a outro plano desse mesmo processo de transformação da cultura popular tradicional com a ideia de reforma dessa cultura.

Nos termos de Burke, a grande e a pequena tradição afastam-

se (cf. item III). O contexto vivo, porém, no qual Rabelais é apreendido permanece; Rabelais é compreendido. A ruptura se consuma na virada do século, expressa na condenação de Rabelais por parte de la Bruyère que considera Rabelais uma monstruosa combinação , condenando-o por ter "semeado esterco em sua obra". O século XVII marca o auge dessa incompreensão e, com ela, a fraqueza do "século das luzes". Voltaire chamava Rabelais de "filósofo bêbado": "No século XVI todos riam, lendo o livro de Rabelais, mas ninguém o desprezava porque fazia rir. No século XVIII, o riso alegre tornou-se desprezível e vil (...). Na prática , contudo, Voltaire (nos romances filosóficos), Diderot (Jacques le fataliste) inspiram-se, de forma limitada e racionalizada, nas imagens rabelaisianas" (BAKHTIN, 1987, p. 100).

Bakhtin aborda então ponto fundamental no conjunto de suas formulações. O sistema de imagens rabelaisianas (realismo grotesco) formalizou-se na escrita, saiu da cultura viva, transmitindo-se agora na tradição literária. Essa formalização é, por um lado, um empobrecimento. O riso voltairiano, de ironia pura, estaria longe, segundo o autor, do riso festivo e alegre. Esse sistema de imagens pode ser usado por várias tendências para fins diversos. Por outro lado contudo, a formalização é outra forma da vida do realismo grotesco: "a riqueza da forma grotesca, carnavalesca, seu vigor artístico e heurístico generalizados, subsistem em todos os acontecimentos literários importantes da época". Sua função, onde quer que esteja, seria a mesma:

ilumina a ousadia da invenção, permite associar elementos heterogêneos, aproximar o que está distante, ajuda a liberar-se do ponto de vista dominante sobre o mundo, de todas as convenções e de elementos banais e habituais (...); permite olhar o universo com novos olhos, compreender até que ponto é relativo tudo o que existe, e, portanto, permite compreender a possibilidade de uma ordem totalmente diferente do mundo (BAKHTIN, 1987, p. 30).

A mesma ideia se expressa no que tange especificamente à festa. No reinado dos cânones artísticos clássicos, nos séculos XVII e XVIII,

a festa quase deixa de ser a segunda vida do povo, seu renascimento e sua renovação temporários. Sublinhamos o advérbio quase porque, na verdade, o princípio da festa popular do carnaval é indestrutível. Embora reduzido e debilitado, ela ainda assim continua a fecundar os diversos domínios da vida e da cultura" (idem, ibidem).

O método grotesco, seu sistema de imagens que sintetiza a essência do carnavalesco, detém um poder heurístico libertador onde quer que se expresse, seja na forma artística, seja na tradição viva. E, mais do que isso, destroços, fragmentos, formas empo- 
brecidas desse mundo guardam o seu poder de renovação, são capazes de recuperar sua vitalidade. Esse poder de renovação e de recuperação chama-se carnavalização:

Na realidade, a função do grotesco é liberar o homem das formas de necessidade inumana em que se baseiam as ideias dominantes sobre o mundo. 0 grotesco derruba essa necessidade e descobre seu caráter relativo e limitado (...). O riso e a visão carnavalesca do mundo, que estão na base do grotesco, destroem a seriedade unilateral e as pretensões de significação incondicional e intemporal, liberam a consciência, o pensamento e a imaginação humana, que ficam assim disponíveis para o desenvolvimento de novas possibilidades. Daí que uma certa "carnavalização" da consciência precede e prepara sempre as grandes transformações, mesmo no domínio científico (BAKHTIN, 1987, p. 44).

Em sua reação aos cânones clássicos, o Romantismo teria ampliado a concepção de realidade, concedendo importância ao tempo e ao devir históricos. Os românticos valorizaram o grotesco, procuraram suas raízes populares. Victor Hugo seria o escritor romântico que expressaria a compreensão mais profunda de Rabelais. Na visão de Bakhtin, o lado negativo do romantismo residiria em seu idealismo, na má compreensão do papel e das fronteiras da consciência subjetiva "que levam o romântico a acrescentar à realidade mais do que ela contém. O fantástico acabou por degenerar em misticismo, a liberdade humana acabou por seccionar-se da necessidade e transformar-se em força supramaterial" (BAKHTIN, 1987, p. 107). O grotesco romântico é um grotesco empobrecido, um "grotesco de câmara: uma espécie de carnaval que o indivíduo representa na solidão e na consciência aguda de seu isolamento" (BAKHTIN, 1987, p. 33). O riso perde seu poder regenerador, é humor, ironia ou sarcasmo. Uma mudança notável ocorre em relação ao terrível. O universo é apresentado agora como alheio ao homem:

tudo que é costumeiro, banal, habitual, reconhecido por todos, torna-se subitamente insensato, duvidoso, estranho e hostil ao homem. O mundo humano transforma-se de repente em um mundo exterior. A reconciliação, quando ocorre, é no plano subjetivo e lírico, por vezes místico" (BAKHTIN, 1987, p. 34).

No grotesco medieval e renascentista, o terrível é vencido pelo riso, vira "bobagem alegre". O romance de Rabelais, mais do que qualquer outro no mundo, exclui o temor. "Graças à força heurística do método grotesco, o romantismo teria, contudo, feito sua descoberta fundamental: a do indivíduo subjetivo, profundo, íntimo, complexo, inesgotável" (BAKHTIN, 1987, p. 38).

$O$ interesse pelo grotesco renasce no século XX, na forma do grotesco modernista (Jarry, os surrealistas, expressionistas) e do grotesco realista (Mann, Brecht, Neruda). Bakhtin se detém nas obras de Kayser e de Lucien Febvre, com as quais dialoga, e defende a hipótese, acima exposta, de que a essência estética do grotesco, sua multiplicidade de significações e força de temas, só pode ser compreendida do ponto de vista da unidade da cultura carnavalesca medieval. 


\section{A NOÇÃO ROMÂNTICA DE CULTURA POPULAR COMO EFEITO DO AFASTAMENTO ENTRE A GRANDE E A PEQUENA TRADIÇÃO}

De acordo com Bakhtin, a obra de Rabelais é indício do apogeu da cultura cômica popular no Renascimento. Transitando para o mundo conceitual de Peter Burke, poderíamos aproximar a ideia de cultura cômica popular com aquela da cultura popular tradicional, cuja transformação que se desenrola até o século XVIII é justamente o alvo do exame proposto. ${ }^{18} \mathrm{~A}$ revolução comercial teria levado a uma idade de ouro da cultura popular tradicional, antes que a revolução comercial e industrial, juntas, a destruíssem. Apesar de Peter Burke utilizar a expressão destruição, creio que a ideia proposta é, antes, a de transformação. $\mathrm{O}$ artesanato rural se expandiu com a prosperidade dos camponeses mais ricos e com a especialização de certos ofícios artesanais. A alfabetização e o livro impresso exerceram forte impacto sobre a oralidade. Para o cantador, assinala Burke, o folheto impresso, podia significar num primeiro momento bem-vinda ampliação do repertório, aumento da renda com a venda de textos (BURKE, 1989, p. 277). A longo prazo,

18 Em Bakhtin esse processo é indicado, como vimos, do ponto de vista estético através da ideia de "formalização" do realismo grotesco.

19 A importância do cantador cego viria atestar essa relação entre oralidade e capacidade de improvisação. porém, poderia revelar-se um aliado traiçoeiro. Burke relaciona a difusão da alfabetização ao declínio do épico, e sua sobrevivência (Bósnia, Rússia, Sicília) à persistência do analfabetismo. ${ }^{19} \mathrm{O}$ conteúdo material do impresso popular, contudo, mais sugere continuidade do que ruptura. Os livretos publicados entre 1500 e 1800 revelam a presença esmagadora da tradição: são os mesmos gêneros, os mesmos textos. Burke comenta: "Começa-se a pensar se a imprensa, ao invés de destruir, não preservou e até difundiu a cultura popular tradicional. Quantas baladas os compiladores poderiam registrar a partir da 'tradição oral' no século XIX se não existissem os folhetos impressos?" (BURKE, 1989, p. 279). As transformações parecem ser mais aditivas do que substitutivas: "Novos tipos de heróis populares vieram se juntar ao tradicional santo, cavaleiro, governante ou fora da lei. O hussardo era uma nova forma de cavaleiro; o contrabandista, uma nova espécie de fora da lei; o empresário, um tipo inteiramente novo de herói" (BURKE, 1989, p. 279).

A cultura popular comercializa-se. No âmbito das festas ocorre uma passagem gradual, que prosseguiria no tempo, de formas mais espontâneas e participativas para espetáculos mais organizados e comercializados para espectadores. Cito um trecho significativo:

Quando Montaigne visitou Loreto em 1581, encontrou a aldeiazinha (e grande centro de peregrinação) cheia de lojas, 'ricamente provida' com velas, rosários e imagens santas, para todo o mundo, como Lourdes ou Assis hoje em dia. Montaigne ficou desapontado com o Carnaval romano, mas estrangeiros como ele continuaram a assisti-lo; na verdade, pode-se afirmar que, nos séculos XVII e XVIII, o Carnaval em Roma ou Veneza se destinava tanto aos habitantes locais como aos visitantes, peregrinos e turistas. As festas certamente 
traziam uma contribuição muito necessária à economia dessas duas cidades, e um contemporâneo calculou que trinta mil pessoas visitaram Veneza no carnaval de 1687 (BURKE, 1989, p. 271).

Esse processo histórico de transformação ocorreu também num nível consciente de "reforma" da cultura popular. Houve uma tentativa organizada por parte das pessoas cultas de modificar as atitudes e os valores do restante da po-

20 Bossuet, arcebispo de Meaux e pregador na corte de Luís XIV, fala em acender fogueiras "de madeira eclesiástica" na noite de São João (BURKE, 1989, p. 253) pulação. A reforma, ligada aos movimentos religiosos católicos e protestantes, evidentemente, variou de região para região, de geração para geração. Católicos e protestantes nem sempre se opunham às mesmas práticas ou, se o faziam, era por diferentes razões. A reforma católica tendia a modificações e adaptações, ${ }^{20} a$ protestante, a supressões. As investidas, evidentemente, concentravam-se no carnaval.

A oposição religiosa à cultura popular atravessou o cristianismo. Diante dela, a cultura popular sempre apresentou extraordinário poder de resistência. Todavia, segundo Burke, as tentativas medievais de reforma eram esporádicas, devido à própria natureza das comunicações da época. Do século XVI em diante, entretanto, trata-se de movimento mais coeso, acompanhado de importante alteração na mentalidade ou sensibilidade religiosa (BURKE, 1989, p. 241). Tratava-se agora de destruir a "tradicional familiaridade com o sagrado" que, na visão devota, alimentava a irreverência. Confrontavam-se nesse processo, a ética tradicional, que "envolvia uma ênfase maior nos valores da generosidade e espontaneidade e uma maior tolerância em relação à desordem", e a ética do ascetismo mundano dos reformadores (BURKE, 1989, p. 237).

A consequência mais óbvia e inesperada desse movimento de reforma foi, segundo Burke, a separação entre a grande e a pequena tradição: "Os reformadores não queriam criar uma cultura própria, expurgada, separada; queriam atingir o povo, trazer todos para o seu lado. Na prática, contudo, as coisas funcionavam de modo diferente. As reformas afetaram mais rápida e cabalmente a minoria culta (...) e assim aprofundaram a separação dessa minoria em relação às tradições populares (BURKE, 1989, p. 263).

A cultura erudita entre os séculos XVI e XVIII transformou-se com extraordinária rapidez (Renascimento, Reforma, Contrarreforma, Revolução científica, lluminismo). Apesar do contato entre os níveis de cultura, o fosso entre eles teria aumentado: as "tradições orais e visuais não conseguiram absorver rápidas transformações ou, para mudar a metáfora, elas eram resistentes às transformações, acostumadas a tomar o novo e transformá-lo em algo muito semelhante ao antigo" (BURKE, 1989: 293). A ideia de tradicional em Burke parece associar-se à de um ritmo e uma reação próprios diante dos processos de transformação. No período moderno, a cultura popular não dispunha de base institucional e econômica para transformar-se rapidamente. O século XIX, com a urbanização acelerada, estradas de ferro, escolarização, viria alterar esse quadro. Por isso o estudo de Burke encerra-se em 1800, quando os descendentes dos homens cultos que haviam dei- 
xado de participar espontaneamente da cultura popular tradicional começam a descobrir e admirar "o povo" "do qual brotava essa cultura estranha" (BURKE, 1989, p. 306).

\section{ALGUMA CONCLUSÃO}

O carnaval ocupa lugar central nessas visões de cultura popular. No caso de Bakhtin, a festa carnavalesca concreta é, sobretudo, o lugar de abrigo do carnaval como princípio e visão de mundo - o realismo grotesco com seu universo de valores característico. Nisso reside a unidade filosófica e moral da noção bakhtiniana de cultura popular cultura cômica, não oficial, pública e festiva. No caso de Burke, o agregado festivo do carnaval é também lugar de abrigo de um espírito de mundo e das expressões da cultura popular tradicional, aquela configuração cultural que abriga a interação assimétrica e, entretanto, profunda entre duas correntes de tradição, a grande e a pequena.

Burke desenvolve retórica mais intelectualista em certo sentido, ao enfatizar muitas vezes a ideia da "invenção" da cultura popular pelo Romantismo. Esse artifício retórico não faz jus à complexidade de seus argumentos. É verdade que um dos pontos altos de seu livro é a clareza com que se circunscreve a gênese histórica do universo de valores abarcados pela visão romântica mais ortodoxa de cultura popular - o puro, o primitivo, o autêntico e... o eternamente degradado -, e sua crítica a esse ponto de vista é especialmente elucidativa. $\mathrm{O}$ modelo das duas camadas (cultura de elite versus cultura do povo) flexibiliza-se por meio da ênfase na heterogeneidade interna aos distintos níveis de cultura e efetua o crucial deslocamento do interesse analítico para as permanentes interações entre esses níveis. Rompe-se, e esse é um notável feito conceitual, a justaposição entre o popular e as fronteiras de grupos ou classes sociais, ou seja, como já observaram os antropólogos que trabalham com as sociedades urbanas e complexas (VELHO, 1981), os limites dos processos culturais não são idênticos aos das camadas, segmentos e grupos sociais. É particularmente esclarecedor o exame da gênese dos estudos de folclore e de cultura popular no Romantismo. É sobretudo neste último sentido que a ideia de "invenção" se aplica. O interesse intelectual que instaura um campo de estudos próprio para o folclore e a cultura popular nasceu em berço romântico e trouxe consigo um conceito novo - o de cultura popular. Entretanto, aquelas expressões e manifestações culturais, que, nesse momento histórico específico, se iluminam e se ressignificam sob essa nova rubrica, trazem elementos e tradições vindos do fundo do tempo. A obra de Bakhtin, sob esse aspecto, é um poderoso contraponto. Afinal, as expressões populares concretas não foram "inventadas" no sentido de instituídas artificialmente pelos intelectuais românticos em um ato de voluntarismo coletivo e consciente. Para dar conta dessa transcendência, Burke se reporta à cultura popular tradicional (enfatizando, com razão, o anacronismo da noção de popular, pois as camadas das elites que participavam dessas expressões não as designavam ou percebiam como alheias a si). Nesse contexto, a noção de oralidade, em especial, ocupa lugar de destaque, embora aqui, novamente, Burke relativize as transfor- 
mações operadas pela escrita que podem trazer novas formas de continuidade e não necessariamente rupturas naquilo que antes só era produzido oralmente.

Finalmente em ambos os autores, a ideia do carnaval associa-se fortemente à ideia da festa como abrigo de uma visão de mundo. Em Bakhtin, essa associação ganha estatura de filosofia de mundo vivida em seu apogeu na Europa medieval, mas nem por isso dela exclusiva. A festa, forma primordial da civilização humana, abriga um princípio transcendente - o cômico grotesco, livre e utópico a relativizar verdades estabelecidas, a celebrar a incompletude, a instaurar a experiência da desordem criativa desde quando os grupos humanos se renovam. A noção de "popular" amplia-se então e vem indicar um aspecto decisivo daquilo que seria, afinal, essencialmente "humano".

\section{REFERÊNCIAS BIBLIOGRÁFICAS}

BAKHTIN, Mikhail. A cultura popular na Idade Média e no Renascimento. São Paulo/Brasília: Ed. Hucitec/Ed. Universidade de Brasília, 1987.

BECKER, Howard. Art worlds. Berkeley: University of California Press, 1982.

BURKE, Peter. A cultura popular na Idade Moderna. Europa 1500-1800. São Paulo: Companhia das Letras. 1989.

CAVALCANTI, Maria Laura Viveiros de Castro. O rito e o tempo: ensaios sobre o carnaval. Rio de Janeiro: Civilização Brasileira, 1999.

. Conhecer desconhecendo: a etnografia do espiritismo e do carnaval carioca. In: VELHO, G. e KUSCHNIR, K. (orgs.). Pesquisas urbanas: desafios do trabalho antropológico. Rio de Janeiro: Jorge Zahar Ed., 2003, p. 118-138.

. Cultura popular e sensibilidade romântica: as danças dramáticas de Mário de Andrade. Revista Brasileira de Ciências Sociais, v. 19, n. 54, fev. 2004, p. 57-78.

Carnaval carioca: dos bastidores ao desfile. 3 ed. revista e ampliada. Rio de Janeiro: Ed. UFRJ, 2006.

. Os estudos de folclore no Brasil. In Seminário Folclore e Cultura Popular. Rio de Janeiro: Funarte, 1992 (Série Encontros e Estudos, 1).

e GONÇALVES, Renata (orgs.). Carnaval em múltiplos planos. Rio de Janeiro: Aeroplano, 2009.

DAMATTA, Roberto. O ofício do etnólogo, ou como ter anthropological blues. In NUNES, Edson de Oliveira (org.). Aventura sociológica: objetividade, paixão, improviso e método na pesquisa social. Rio de Janeiro: Zahar Eds., 1978, p.23-35.

Treze pontos riscados em torno da cultura popular. Anuário Antropológico. 1992. Rio de Janeiro: Tempo Brasileiro, 1994, p. 49-67.

GONÇALVES, José Reginaldo Santos. Autenticidade, memória e ideologias nacionais: a questão dos patrimônios culturais. In ESTERCI, N. et al. (orgs.). Fazendo antropologia no Brasil. Rio de Janeiro: DP\&A/Capes, 2001, p. 15-33.

A retórica da perda: discurso nacionalista e patrimônio cultural no Brasil. 2. ed. Rio de Janeiro: Ed. UFRJ, 2002 [1996].

JAKOBSON, Roman e BOGATYREV, Peter. Le folklore, forme spécifique de la création. In JAKOBSON, Roman. Questions de poétique. Paris: Éditions du Seuil, 1973 [1929], p. 59-72. 
ORTIZ, Renato. Cultura popular: românticos e folcloristas. São Paulo: PUC, 1985.

REDFIELD, Robert. Peasant society and culture. Chicago: Chicago University Press, 1956.

SIDRO, Annie. Le Carnaval de Nice et ses fous. Nice: Éditions Serre, 1979.

TODOROV, Tzvetan. Mikhail Bakhtin: the dialogical principle. Minneapolis: University of Minnesota Press, 1984.

VELHO, Gilberto. Observando o familiar. In NUNES, Edson de Oliveira (org.). Aventura sociológica: objetividade, paixão, improviso e método na pesquisa social. Rio de Janeiro: Zahar Eds., 1978, p.36-46.

. Individualismo e cultura: notas para uma antropologia da sociedade contemporânea. Rio de Janeiro: Zahar Eds., 1981.

VOLVELLE, Michel. Ideologias e mentalidades. São Paulo: Ed. Brasiliense, 1978.

Maria Laura Viveiros de Castro Cavalcanti é antropóloga e professora do Departamento de Antropologia Cultural e do Programa de Pós-Graduação em Sociologia e Antropologia no Instituto de Filosofia e Ciências Sociais da Universidade Federal do Rio de Janeiro. É autora de Carnaval carioca: dos bastidores ao desfile (Ed. UFRJ, 1994), O rito e o tempo: ensaios sobre o carnaval (Civilização Brasileira, 1999) e organizadora, com Renata Gonçalves, de Carnaval em múltiplos planos (Ed. Aeroplano, 2009).

Artigo recebido em julho de 2010 e aceito para publicação em julho 2010. 
